本文引用格式 / Please cite this article as:

Liu, Y. F., Mou, T. T., Huang, Z. W., \& Ha, R. G. (2019). Research on Visually Perceived Image and Strategies for Vista View System Improvement of the Jinsitao Waterfront of Shichahai in Beijing Landscape Architecture Frontiers, 7(2),121-131. https://doi.org/10.15302/J-LAF-20190212

\section{北京什刹海金丝套滨水空间的视觉感 知意象研究与眺望景观优化策略 RESEARCH ON VISUALLY PERCEIVED IMAGE AND STRATEGIES FOR VISTA VIEW SYSTEM IMPROVEMENT OF THE JINSITAO WATERFRONT OF SHICHAHAI IN BEIJING}

刘神绯*

北京林业大学园林学院城乡规划系副教授; 美国伊利诺伊理工学院建筑学院景观系博士后; 清华大学建 筑学院建筑学博士

牟婷婷

万科企业股份有限公司北方区域产城产办事业部产品专员; 北京林业大学园林学院城乡规划系硕士

黄子薇

北京林业大学园林学院城乡规划系本科在读

哈日桂

清华大学建筑学院城市规划系硕士在读

LIU Yifei

Associate Professor of Department of Urban and Rural Planning, School of Landscape Architecture, Beijing Forestry University; Postdoctoral Fellow, Department of Landscape Architecture, School of University

MOU Tingting

Product Specialist, Industry Town and Office Business Unit of North Region of China Vanke Co., Ltd.: Master in Urban and Rural Planning, School of Landscape Architecture, Beijing Forestry University

HUANG Ziwei

Undergraduate Student of Department of Urban and Rural Planning, School of Landscape Architecture, Beijing Forestry University

HA Rigui

Graduate Student of Department of Urban Planning, School of Architecture, Tsinghua University

\section{大通讯作者}

地址：北京市海淀区北京林业大学学研中心1315A

邮编: 100083

那箱: liuyifeibjfu@qq.com
https://doi.org/10.15302/J-LAF-20190212 收稿时间 RECEIVED DATE / 2019-02-05 中图分类号/ TU984 文献标怾码/ B
摘要

视觉感知是人们感受环境并产生意象的最直 接的方式之一，亦是城市意象研究的重要数据来 源。本文以北京什刹海金丝套滨水空间为研究对 象，基于由穿戴式相机获取的图片数据和对数据 进行处理后得到的意象感知体系, 探索对该地区 眺望景观进行优化的规划设计策略，以为城市历 史街区的景观提升提供参考。研究选取前海北沿 至后海南沿共 $800 \mathrm{~m}$ 的路径作为游线, 采集30位 志愿者穿戴便携式摄像机GoPro的游览影像, 按 每秒一帧连续截取25000余张图片; 随后，通 过识别和分析图片中的意象并对感知点和感知对 象进行空间定位, 可得到基于视觉的意象感知体 系；进而建议：在历史地段的规划中应当更加注 意整体风貌的营造以及重要标志物的打造，优化 景观视线廊道, 构建完整的眺望景观体系。

关键词

城市意象; 视觉感知; 可穿戴设备; 历史地段; 眺望景观

\section{ABSTRACT}

Visual perceiving is one of the most important and direct ways to perceive physical environment and instantly generate images of it. The data gained from visual perception lays a foundation for the research on city images. This study concentrated in the Jinsitao Waterfront of Shichahai area in Beijing. By collecting photos with wearable cameras and generating an image map of visual perception through image identification and analysis, this study explores strategies for improving vista view system in the study area, offering a reference for other research on historical district renewals in cities. Thirty volunteers were asked to tour along an 800-meter path from the north edge of Qianhai to the south edge of Houhai recording the scenery with screenshots were then captured consecutively from the video documents. By identifying and analyzing these screenshots, mapping perceiving locations, and corresponding them to perceived objects, an image perception map was generated, from which a series of planning and design strategies were developed to suggest that future historical districts' planning practices should enhance the protection of a site's overall image and distinctive landmarks, as well as the improvement of visual corridors and vista view system

\section{KEY WORDS}

City Image; Visual Perception; Wearable Device: Historical Site; Vista View System GoPro cameras on their foreheads. Over 25,000

基金项目

国家自然科学基金项目“城市历史景观框架下古城意象的多尺度研究” ( 编号: 51608035

北京市社会科学基金项目 “北京中轴线的城市历史景观眺望系统研究” (编号：18LSC009)

北京林业大学国家级大学生创新创业训练计划“基于GoPro的历史滨水街区视线研究”（编号：201810022013 )

\section{Research Funds}

A Multi-Scale Research on the Image of Historic Cities under the Framework of Historic Urban Landscape, National Natural Science Funds of China (No. 51608035);

Research on the Vista View System of the Urban Historic Science Foundation (No. 18LSC009)

Research on the Sight of Historic Waterfronts Using GoPro, National Training Program of Innovation and Entrepreneurship for Undergraduates of Beijing Forestry University (No.201810022013)

编辑 汪默英 余依爽 翻译 田乐

EDITED BY WANG Moying SHEYishuang TRANSLATED BY Tina TIAN 


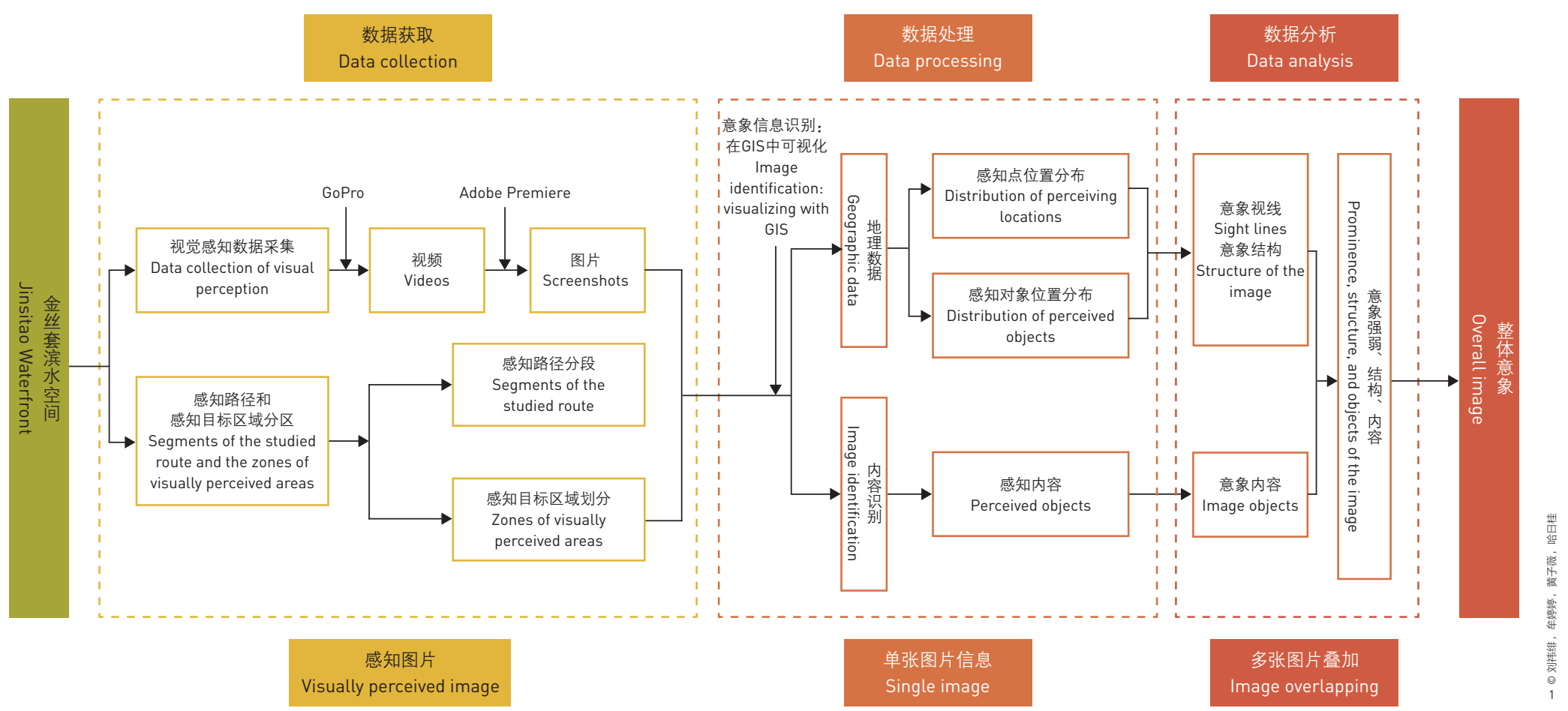

\section{1 项目背景}

自凯文 - 林奇首次将认知地图法引人城市相关学科以来 ${ }^{[1]}$, 该方法 已成为获取与城市设计、城市规划相关的社会数据最常用的方法之 - ${ }^{[2]-[5]}$ 。2000年以来, 城市意象数据采集的手段发展迅速, 除传统的认 知地图、照片识别、问卷调查以外, 还出现了焦点小组访谈等各类访 谈法 ${ }^{[6]}$ 、游客受雇拍摄法 ${ }^{[7]}$ 、动线观察法 ${ }^{[8]}$ 、分析并提取图像或文字等媒 介信息 ${ }^{19}$ 等新方法。此外, 伴随着大数据、新数据时代的到来, 运用新 兴设备与技术进行意象采集的研究也在近 10 年纷纷涌现 ${ }^{[10\}-[15]}$ 。

视觉感知是人们感受环境并产生意象的最直接的方式之一 ${ }^{[15][16]}$ 。 不论是传统的认知地图、照片识别、问卷调查法, 还是访谈法等新 方法, 都难以避免记录人对感知内容的主观篮选; 而视觉感知图像则 可以无差别地记录物质空间环境, 为后续分析提供更多原始素材。此 外, 视觉感知图像还携带着地理信息与拍摄时间信息, 能够直观地与 空间和时间相关联。由于具备客观、稳定、全面等特点, 基于视觉感 知的意象研究已成为近年的研究热点 ${ }^{[15]-[2]}$ 。

在现有针对历史地段的意象研究中, 认知地图、问卷调查等方法 依旧占据主导 ${ }^{[12 \mid 22]-124]}$, 网络数据也在近年来逐渐受到重视 ${ }^{[25]}$, 但感知图 像数据由于相对难以获取和利用, 尚少有应用。《北京城市总体规划
（2016-2035）》明确提出, 应 “构建看城市、看山水、看历史、看风 景的城市景观眺望系统”。作为对该规划要求的一次实践探索, 本研 究聚焦于北京老城什刹海金丝套地区滨水空间, 基于由穿戴式相机获 取的图片数据和对数据进行处理后得到的意象感知体系, 探索对该地 区眺望景观进行优化的规划设计策略, 以为城市中的历史街区景观提 升提供参考（图1）。

\section{2 数据采集与处理}

\section{1 数据采集}

研究将北京老城什刹海金丝套滨水空间中观景体验优越的前海北 沿至后海南沿全长 $800 \mathrm{~m}^{\circledR}$ 的路段设定为意象采集路径, 邀请 30 位学生 志愿者利用可穿戴设备采集各自的视觉感知视频。志愿者年龄在18 25 岁, 男性13名, 女性17名, 均为城乡规划或风景园林相关学科本科生 或研究生。研究所采用的GoPro摄像机具有小巧轻便、画面稳定、画质 清哳等优势。志愿者须将设备佩戴于额头上, 以使采集画面更加接近 真实的视觉体验 (图2)。为了确保佩戴方式正确、调研路线统一, 研 究团队于2017年6月对志愿者进行了集中培训, 并要求其于2017年7 11 月间下午时段各自前往场地采集感知视频。但是, 考虑到后续数据处
(1) 为方便后续数据处理, 本研究截取了沿道路中 线距离 $800 \mathrm{~m}$ 的采集路 径, 涵盖金丝套地区绝 大部分的滨水空间。 
1. 技术路线：研究主要从 视觉盛知音象数坦的罗 取、处理及分析

2. 志愿者将GoPro相机佩 戴于额头上

3. 通过GoPro相机采集到 的视觉感知视频截图

1. Roadmap: the study focuses on the data colus and analysis of image by visual sensing.

Volunteers wearing GoPro Camera on their foreheads

Screenshots captured from the videos take with GoPro Cameras

理工作量庞大，此次实验仅收集了从前海北沿至后海南沿正向行走时 的视频，以从方法上提供示例

\section{2 数据处理}

在得到感知视频后, 研究团队首先用Adobe Premiere软件将总长约 418 分钟的 30 条视频按每秒一帧截取为图片, 共得到 25089 张连续感知 图片（图3），随后通过大量的人工识别工作读取图片中的信息。这些 感知图像包含至少三项基本信息: 感知点、感知对象和感知时长。其 中, 感知点指人们产生意象时所在的观测位置, 感知对象指感知到的 具体意象内容, 感知时长指某种感知意象持续的时间。这些信息共同 构成金丝套滨水空间的整体意象。
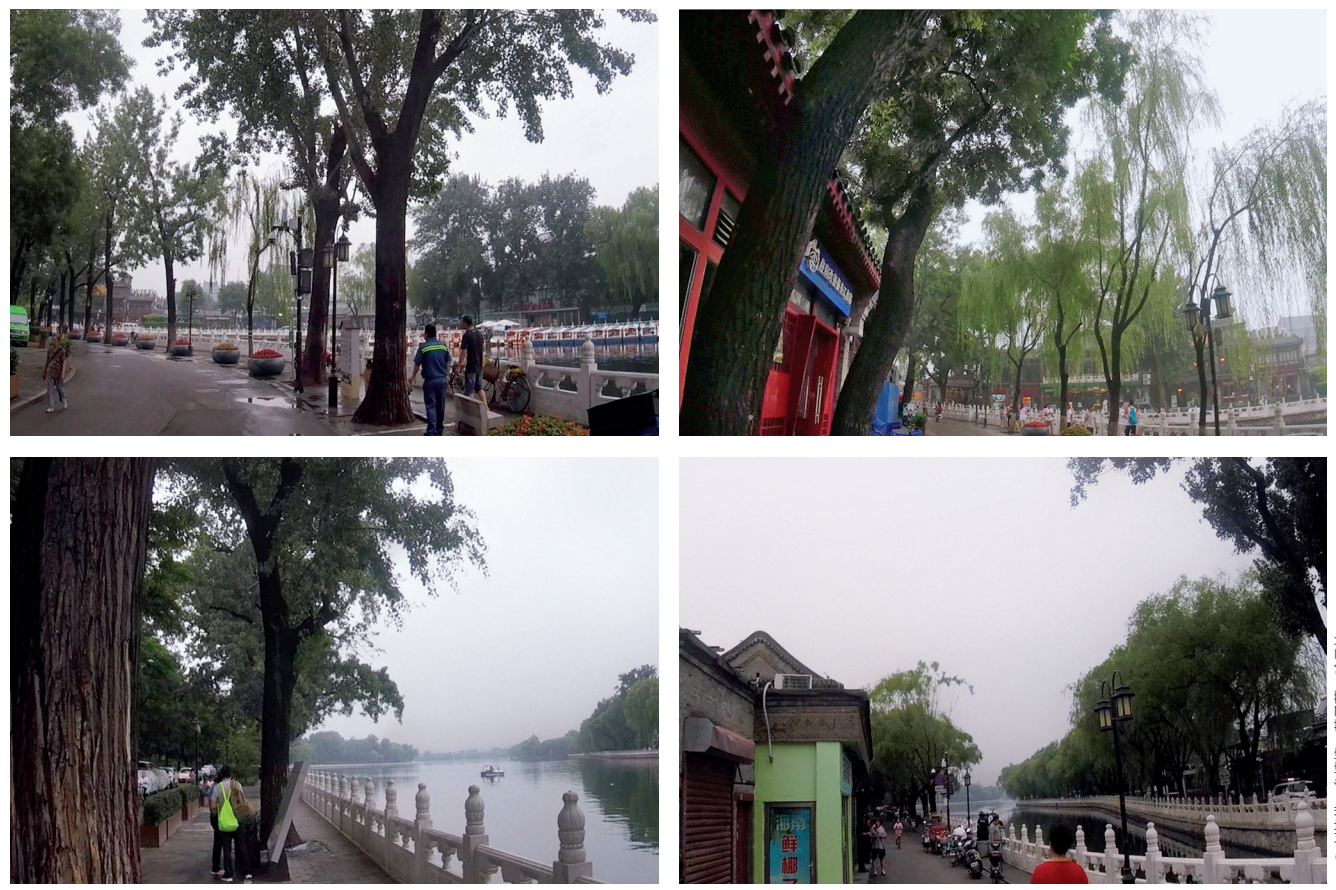

为便于后续的意象数据统计和空间落位, 研究团队首先将总长 $800 \mathrm{~m}$ 的感知采集路径以 $25 \mathrm{~m}$ 为一段均匀划分为 32 段，并从南至北依次 标号。

随后，团队对感知目标进行了划分。由于本研究主要聚焦于眺望 景观，且实验前进方向右侧滨水景观的照片占比 (69\%) 远高于左侧临 近街铺（31\%）（图4）, 因此, 研究主要就右侧滨水景观展开讨论, 并将其按景观特色进行归纳, 划分为 13 个景观空间单元，并依次编号 为 $\mathrm{A} \sim \mathrm{M}$ 区段（图5）。其中，由于潭苑景区在研究区段内视线不可达， 故没有列人景观空间单元。

最后，团队将从感知图片中提取的感知点、感知对象的空间落位 以及二者的视线连线在地理信息系统 (GIS) 中进行了可视化, 得到了 基于视觉感知的意象地图（图6）。

\section{3 视觉感知意象研究}

从视线的角度来理解，感知点、感知对象和感知视线与眺望点、 眺望对象和朓望视线呈一一对应关系, 因此, 视觉感知意象地图也反 映了该地区的眺望景观现状 (图7)。对感知点、感知对象和感知视线 进行分析, 可以得到重要眺望视域, 以为下一步提出眺望景观优化策 略提供依据。

\section{1 感知点分析}

感知点的分布情况反映了观者在游览过程中在不同位置的观赏/停 留意愿。从图 5 可以看出, 观者在停留空间充足、拥有丰富眺望景观 （包含金锭桥、火神庙、钟楼、鼓楼、银锭桥等）的1 16段停留时间 较长, 在眺望景观变化较小且缺乏停留空间的17 32段停留时间较短。 整个游览过程中停留时间最长的三次视觉感知高潮分别出现在视线开 阔且有停留空间的1 2段、最初眺望到钟鼓楼的7 9段, 以及最初远观 到西山的13 15段。

\section{2 感知对象分析}

分析结果显示，志愿者感知到的对象的意象强弱差别巨大，其中 意象较为突出的有前海南沿居住区段 ( C区段) 、前海东沿可见钟鼓楼 区段（G区段）、银锭桥及周边区段（I区段）、望海楼周边历史文化 区段（L区段），以及远景可见西山区段（M区段）。说明人们对金丝 套滨水空间周边可见的各类重要的景观标志物感知强烈, 例如, 上述 区段分别对应了银锭桥、钟鼓楼、西山、湖心岛、望海楼等历史建筑 或景观要素。

\section{3 视线分析}

经分析共得到109条强度各异的视线。如图6所示，红色表示视线 出现的频次较多, 绿色表示出现的频次较少。总体而言, 前海区域的 视线强度高于后海区域。其中强度最高的6条视线包括：1 2段一湖心 
岛视线、1 2段-C区段视线、2段-金锭桥视线、5段一火神庙视线、9 段一鼓楼视线, 以及14 15段一西山视线。

\section{4 酐望景观提升策略}

基于可穿戴设备对视觉感知意象的精准记录和后续分析, 团队发 现研究场地沿途普遍存在重要眺望对象被遮挡、视野混杂、无处驻足 等问题。

基于研究结果, 团队首先选出 7 个重要的感知点和 16 个意象突出的 感知对象, 作为后续规划设计中着重考虑的眺望点与眺望对象 (表1, 图7)。就眺望点 (感知点) 来看, 其中 $\mathrm{a}$ 点、 $\mathrm{b}$ 点和银锭桥已有小块停 留休䕀空间，其余点则需增设休䡯设施使其成为节点。

随后, 根据人们对于眺望对象感知意象的强弱, 将研究区域的眺 望景观划分为 4 个保护层级 (图7):

1 ) 眺望空间保护区 (红色)：是指由强意象的眺望点、眺望对象 与眺望视线 (从眺望点出发与眺望对象外轮廓线相切) 共同围合成的 区域。由于宋庆龄故居、醇亲王府 (北府), 以及 $A 、 D 、 E 、 G 、 J$ 和M 区段岸线的意象相对较弱, 因此未纳人这一层级。在此区域中不能出 现过高的构筑物, 以免从眺望点望向眺望对象的视线受到遮挡。

2 ) 近景保护区 (绿色) : 包括眺望点与眺望对象 $30 \mathrm{~m}^{2}$ 半径范围内 的区域。建议在眺望点近景设计中, 加强对眺望对象的视线引导; 同 时以眺望对象为核心, 对相应区域内的景观和建筑物进行相应的详细 设计, 以突出眺望对象的感知意象。

3 ) 远景保护区 (粉色): 是以眺望点为圆心, $180 \mathrm{~m}^{2}$ 半径范围内 的区域。建议为此区域内的景观及建筑物的形态、层数、材质制定具 体的详细控制导则，使其与近景保护区风貌相协调。

4 ) 背景保护区 (蓝色) : 是眺望点以眺望对象为中心展开的 $45^{\circ}$
视角 ${ }^{2}$ 范围内的区域。建议对此区域内的景观及建筑物风格、限高、色 彩做控制性规划，使其不影响整体的风貌感知。

\section{5 总结与反思}

可穿戴设备的涌现使直接采集真实客观的视觉感知影像成为可 能, 为基于视觉感知的意象研究和规划设计提供了新思路、新方法、 新数据。在强调全面提高城市精细化管理水平的今天, 我们更应在历 史地段的保护工作中注重完整眺望景观体系的保护、恢复与营造。

此外, 该研究仍有很大的提升空间。其一, 志愿者样本量较少、 年龄范围较集中, 代表性不够全面, 需扩大样本量和多样性进行进一 步验证; 其二, 数据收集和分析过程耗费人力较大且耗时较长, 希望 未来可以利用计算机技术及人工智能进行处理; 其三, 由于实验数据 采集周期过长, 场地中的植被状态呈现一定变化, 因此, 在视觉意 象研究和规划设计中需考虑植被季相变化对眺望景观的影响。今后同 类型的研究可以从以上各方面加以完善, 以提供更加精准的规划设计 依据。LAF

\section{项目信息}

项目地址: 北京市西城区

研究范围: 约 $800 \mathrm{~m}$

项目负责人: 刘祎绯

项目团队：牟婷婷、哈日桂、成思凡、张雨晴、任笑涵、梁静宜、郭晨㬢、陈䜭琳、黄子薇、南晶娜、徐

昂扬、刘畅、吴佳馨、骆言、李吴霖、孙平天、马賽雨

研究时间: 2017 2018年

注释

本文原始数据欢迎邮件来函索要。
(2) 半径值与视角值的选取均 参考世界各地眺望景观 究和规划的通常做法
4. 实验前进方向右侧滨 水景观的昭片占比 (69\%) 远高手左侧比 近街铺 $(31 \%)$ 。
4. In terms of perceived objects, most collected images $(69 \%)$ reflected the lake area and beyond (on the right of the rest recording the storefront on the left (31\%).

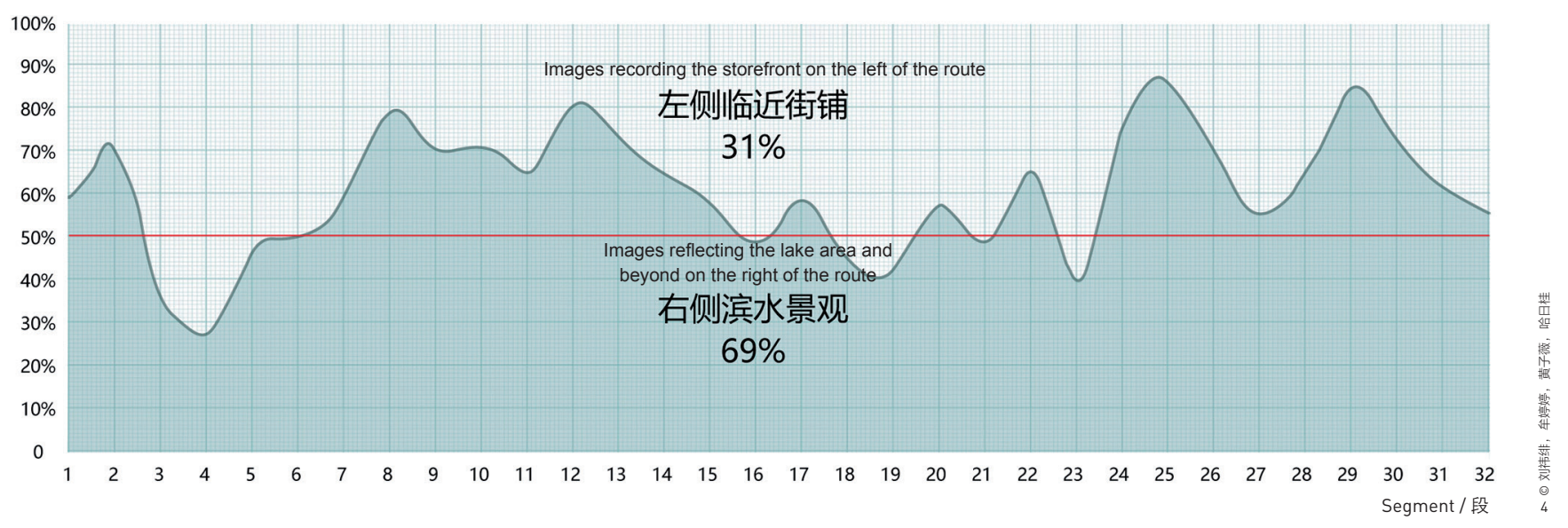




\section{Project Background}

Mapping has been a commonly used method to obtain social data in urban planning and design practice, since Kevin Lynch first introduced it into urban science disciplines ${ }^{[1] \sim[5]}$. From the very beginning of the century, methods of collecting city image data have seen a rapid development. New methods such as interview-based investigation like focus group survey ${ }^{[6]}$, touristemployed photography ${ }^{[7]}$, trace observation ${ }^{[8]}$, and graphic and text recognition ${ }^{[9]}$ have emerged, in addition to cognitive mapping, image identification, questionnaire survey, and other traditional approaches. In this era of big data and new data types, ever-changing devices and technologies have also contributed to the promotion of image research in the past decade $^{[10] \sim[15]}$.

Visual perception is one of the most important and direct ways to perceive physical environment and instantly generate images of what one perceives ${ }^{[15][16]}$. The perception through methods such as cognitive mapping, image identification, questionnaire survey, and interview-based investigation is inevitably subjective. By contrast, images taken by visual sensing devices that fairly, continuously, and comprehensively record the physical environment can better inform perception research. Such images also contain accurate information of taken location and time. Visually perceived image has become a research highlight in recent years ${ }^{[15] \sim 21]}$.

Today, traditional methods like cognitive mapping and questionnaire survey are still dominant in current urban image studies on historical places ${ }^{[12][22]-[24]}$, with an increasingly wide application of online data in recent years ${ }^{[25]}$. However, visual perception data is difficult to access or being utilized. According to Beijing Urban Master Plan (2016-2035), the city is expected to build its vista view system to celebrate its charm of urban construction, natural landscapes, and historic and cultural landscapes. As an authentic exploration, this study concentrated in the Jinsitao Waterfront of Shichahai area in the historic center of Beijing. By collecting photos with wearable cameras and generating image maps by identification and analysis of the photos, this study put forward planning and design strategies for improving the vista view system in the study area, offering a reference for other research on historical district renewals in cities (Fig. 1).

\section{Data Collection and Processing}

\subsection{Data Collection}

In this study, 30 undergraduate and postgraduate students as volunteers (13 males and 17 females) majored in Urban and Rural Planning or Landscape Architecture, aging from 18 to 25, were asked to tour along an 800 -meter path ${ }^{\circledR}$, with the wearable GoPro Camera (a small and light camera that can produce stablyshot and high-quality photos or videos) on forehead (Fig. 2), from the north edge of Qianhai to the south edge of Houhai, the best-sightseeing route in the Jinsitao waterfront area. They were trained in June 2017 about how to use the camera and the expected route for this study. From July to November 2017, each volunteer toured along the route in afternoon and recorded uninterrupted videos on the site. Considering the heavy data processing work, in this study volunteers were only asked to record the scenery along the route from the north edge of Qianhai to the south edge of Houhai, as a methodological demonstration and discussion.

\subsection{Data Processing}

The total length of the 30 videos was about 418 minutes. Adobe Premiere was used to capture one screenshot per second consecutively from the videos, and finally 25,089 screenshots were produced (Fig. 3). Then three kinds of information were identified manually from the screenshots: where the viewer was standing when an image formed; what object the review perceived; and how long the image perception lasted. The overall image of the Jinsitao Waterfront was formed with all the individual perception images.

For an easier integration and mapping of image data, researchers divided the 800-meter route into 32 segments (each of 25 meters in length), and named them from Segment 1 to Segment 32 from the south end to the north.

In terms of perceived objects, most collected images (69\%) reflected the lake area and beyond (on the right of the route), in contrast to the rest recording the storefront on the left (Fig. 4). Considering the study objective of improving the vista view system on the site, the research mainly focused on the lake area by further dividing it into 13 Zones according to spatial and landscape characteristics, and named them with from Zone A to Zone M, from Qianhai to Houhai (Fig. 5). The Tanyuan area was not covered because of the absence of video documents.

Finally, by visualizing the perceiving locations, perceived objects, and the sight lines between viewers and objects with the Geographic Information System (GIS), an image map of visual perception was formed (Fig. 6).

\section{Research on Visually Perceived Images}

In this study, analyzing the relations between perceiving 


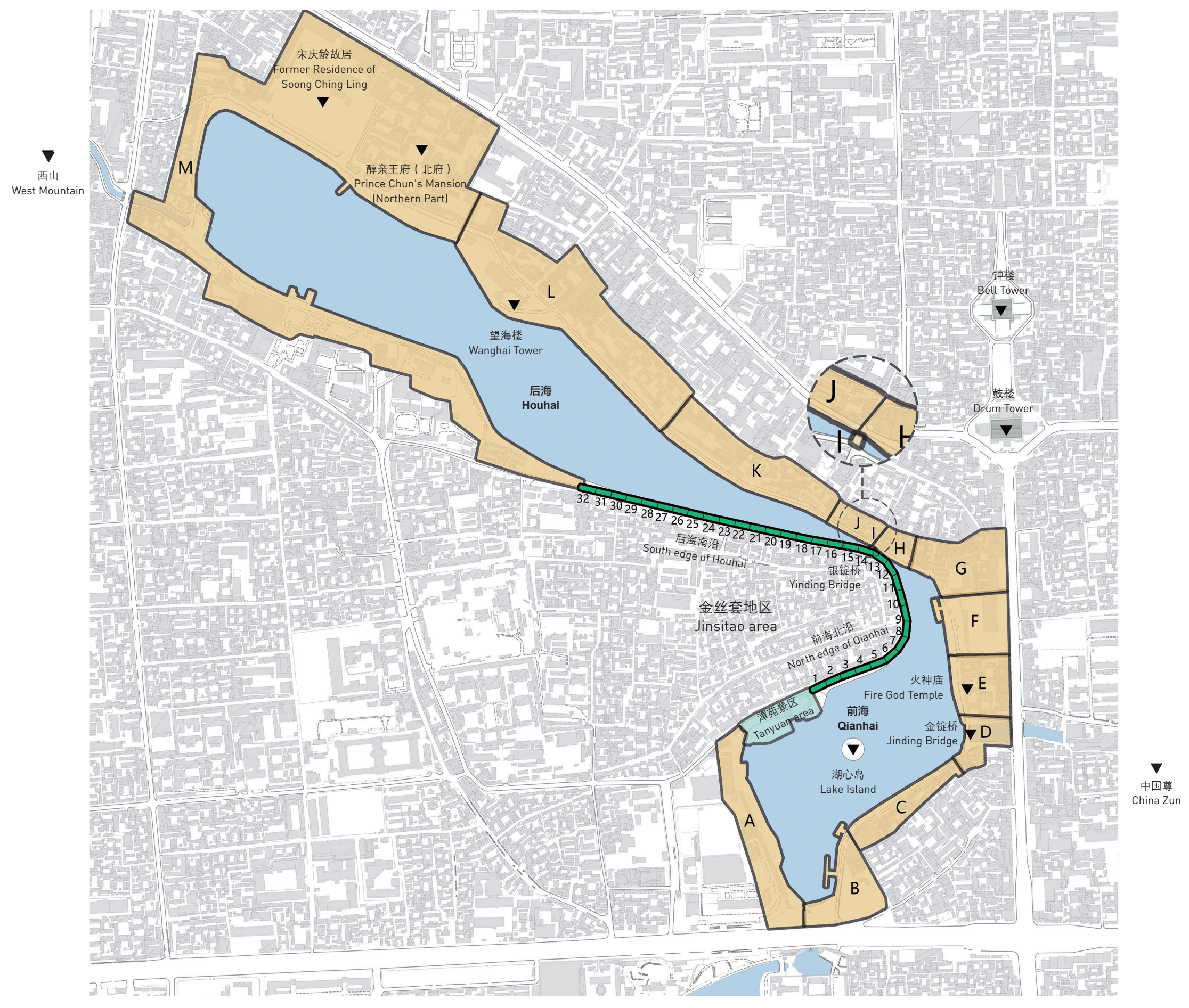

(1)

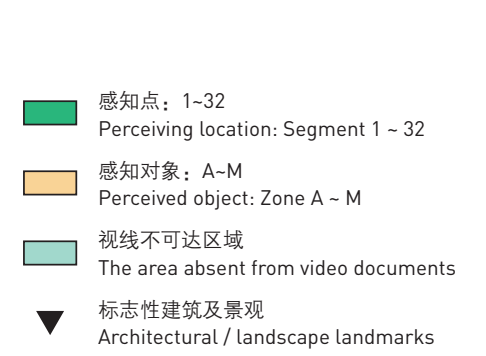

A 荷花市场区段
Lotus Market area
B 前海广场及码头区段
Qianhai Plaza and pier area
C 前海南沿居住区段
The residential area at the south edge of Qianhai
D 金锭桥及周边区段
Jinding Bridge and surrounding area
E 火神庙及周边区段
Fire God Temple and surrounding area

F 地安门百货商场及周边区段

Di'anmen Emporium and surrounding area

$G$ 前海东沿可见钟鼓楼区段

The area with Bell Tower and Drum Tower as a backdrop

$\mathrm{H}$ 前海东沿酒楼区段

The restaurant area at the east edge of Qianhai

银锭桥及周边区段

Yinding Bridge and surrounding are

后海北沿酒吧街区段

Bar street area at the north edge of Houhai

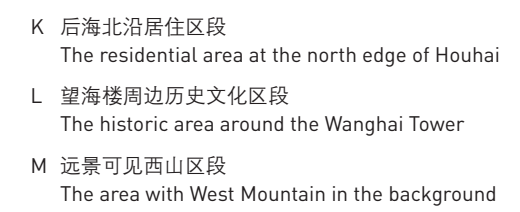



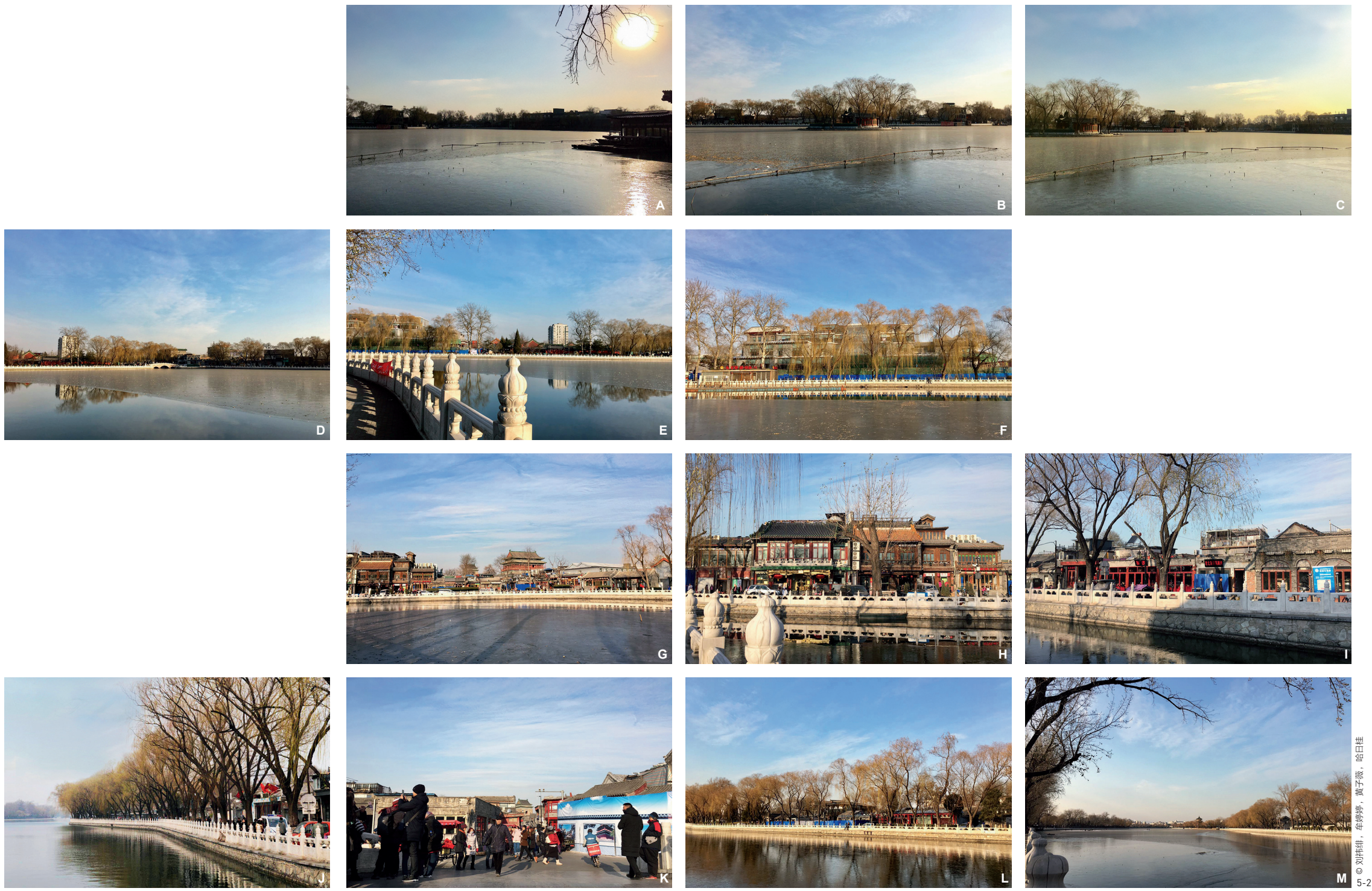

5. 感知路径和感知目标区 域的分区情况

5. Segments of the studied route and the zones of visually perceived areas locations, perceived objects, and sight lines helps reveal the distribution and quality of the existing vista view system on the site (Fig. 7), through which important visual corridors of vista view system can be identified, offering a basis for developing improvement strategies.

\subsection{Perceiving Location Analysis}

The distribution of perceiving locations reflects viewers' watching / staying preference. Figure 5 shows that viewers spent more time around the part from Segment 1 to 16 where diverse recreational places and historical landscapes (including the Jinding Bridge, Fire God Temple, Bell Tower, Drum Tower, and Yinding Bridge) were observed, while spending less time from Segment 17 to 32 where they enjoyed less historical landscape and recreational space. Specifically, Segment 1 and 2 with open horizon and a number of recreational spaces, Segment 7, 8 , and 9 where the Bell Tower and Drum Tower came into view, and Section 13,14, and 15 where the viewers encountered the West Mountain in distance were the top three places where the viewers had the longest stay. 


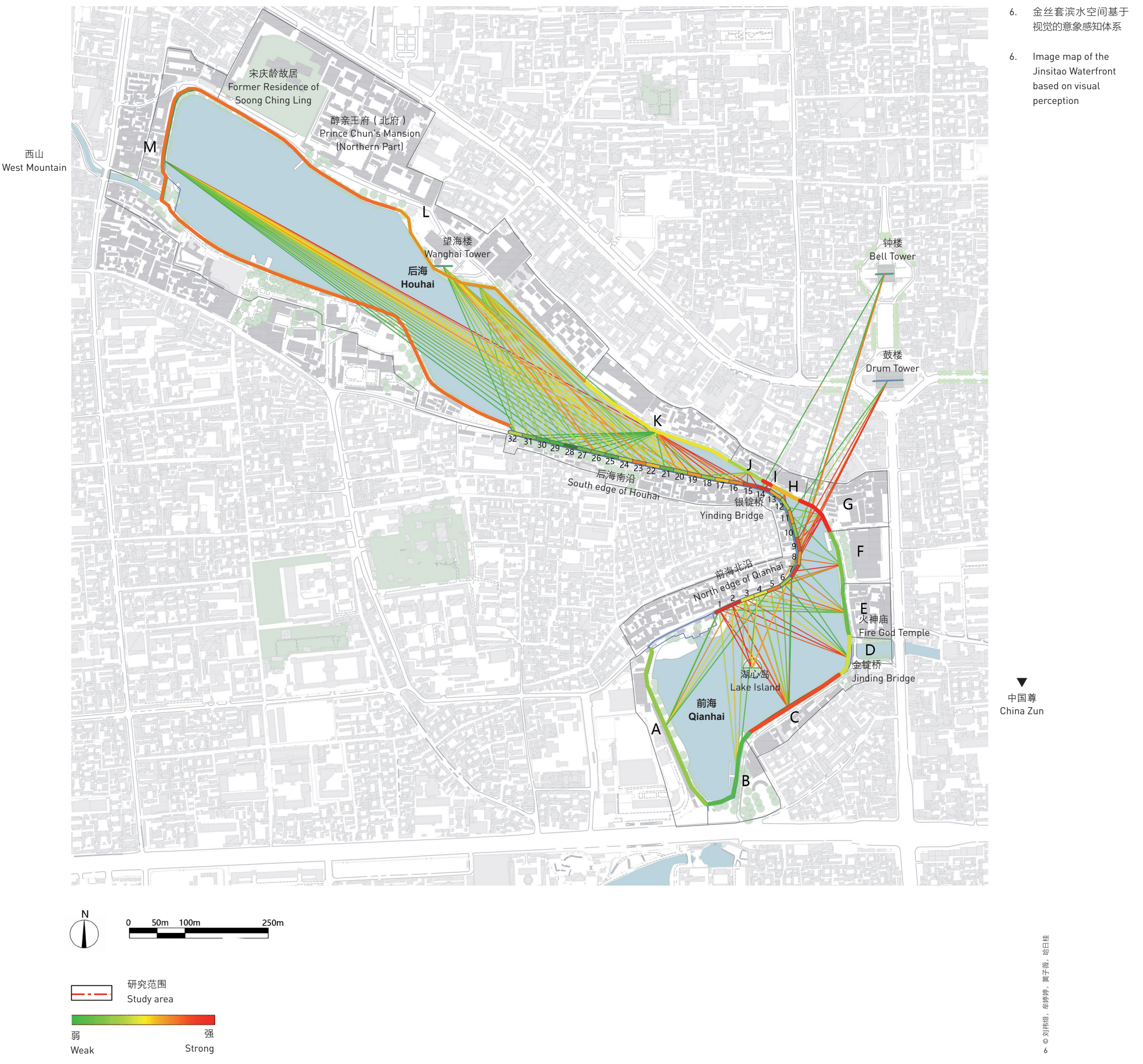


表1：在后续规划设计中应着重考虑的眺望点与眺望对象 Table 1: Key watching points and scenic objects that need a priority in future planning and design practice

\begin{tabular}{|c|c|}
\hline $\begin{array}{c}\text { 眺望点 } \\
\text { Key watching points }\end{array}$ & 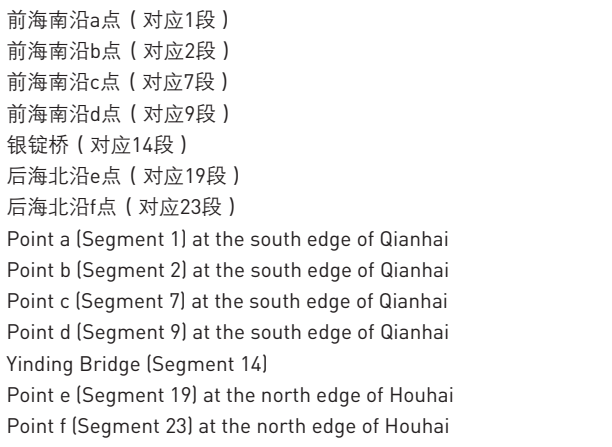 \\
\hline $\begin{array}{c}\text { 眺望对象 } \\
\text { (包含建筑/景观地标) } \\
\text { Key scenic objects } \\
\text { (including architectural } \\
\text { / landscape landmarks) }\end{array}$ & 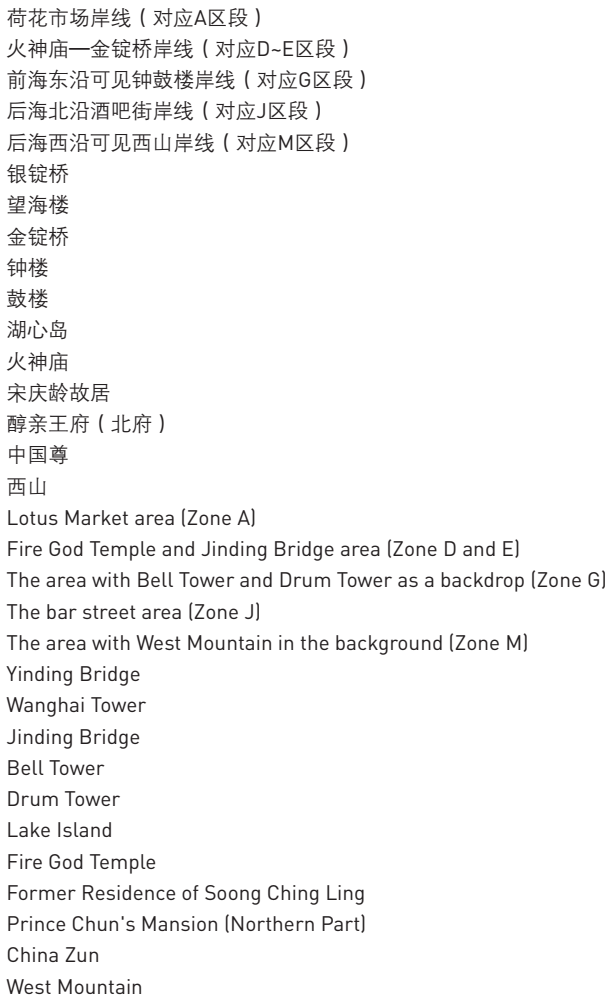 \\
\hline
\end{tabular}

\subsection{Perceived Object Analysis}

Perceived object analysis reveals that viewers' perception on the images of the perceived objects varied dramatically. The most perceived images included the residential area at the south edge of Qianhai (Zone C), the area with Bell Tower and Drum Tower as a backdrop (Zone G), the Yinding Bridge and surrounding area (Zone I), the historic area around the Wanghai Tower (Zone L), and the area with a background of West Mountain in distance (Zone M). It discloses that people have a stronger perception on architectural / landscape landmarks of the Jinsitao Waterfront, such as the Yinding Bridge, Bell Tower and Drum Tower, West Mountain, Lake Island, and Wanghai Tower, each of which characterized its zone.

\subsection{Sight Line Analysis}

By sight line overlapping, 109 sight lines were identified in total (Fig. 6). In the image map, the sight lines with a higher frequency are colored in red (most of which were mapped in the Qianhai area) while those with a lower frequency being colored in green. Six dominant visual corridors are further identified, namely the ones from Segment $1 / 2$ to the Lake Island, from Segment 1 / 2 to Zone C, from Segment 2 to Jinding Bridge, from Segment 5 to Fire God Temple, from Segment 9 to Drum Tower, and from Segment 14 / 15 to West Mountain.

\section{Strategies for Image Improvement of Vista View System}

Based on the visual perception analyses, the researchers found that, in this study area, many important vista-view architectural / landscape landmarks were blocked, sightseeing experience was poor, and observation place lacked.

Informed with the analyses, researchers identified 7 important perceiving locations and 16 prominent perceived objects with strong perceived images as the key watching points and scenic objects for future planning and design practice (Table 1, Fig. 7). Among the key watching points, recreational space was observed at Point a, Point b, and the Yinding Bridge; more amenities need to be introduced into the rest areas.

Researchers then classified all the visual corridors into four image protection levels according to individual importance of image perception of the study area (Fig. 7).

1) Protected vista-view visual corridors (shown in red): These corridors are defined by the horizon between the key watching points and the outline of the scenic objects. The Former Residence of Soong Ching Ling, Prince Chun's Mansion (Northern Part), and Zones A, D, E, G, J, and M are not covered because of their less importance in image perception. Within 


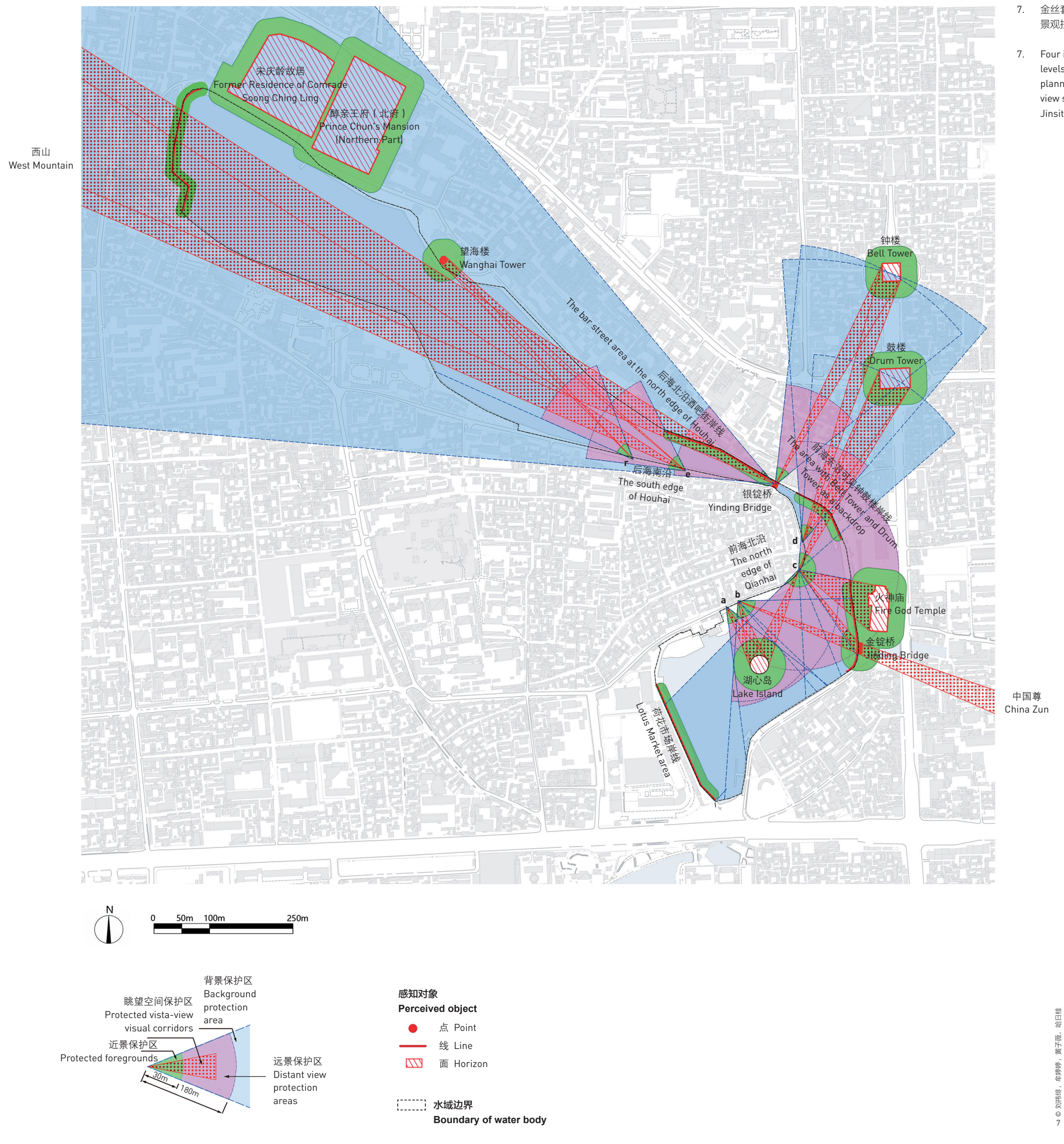



study are adopted from common references in international research and planning of vista view system. these corridors, tall structures should be forbidden to ensure the visual continuity.

2) Protected foregrounds (shown in green): Protected foregrounds cover all the areas centered with key watching points or scenic objects with a radius of 30 meters ${ }^{2}$.

Visual leading to scenic objects should be enhanced in the foreground design of watching points; as to the foreground of scenic objects, a detailed design on landscape and buildings is needed to highlight the image of landmarks.

3) Distant view protection areas (shown in pink): A distant view protection area covers a broader territory of a key watching point, with a radius of 180 meters. Detailed design guidelines of landscape and architectural shape, storey limits, and materials should be introduced in line with that of the protected foreground areas.

4) Background protection area (shown in blue): A background protection area of a key watching point is framed by a $45^{\circ}$ horizon with a central sight line to a certain scenic object. Directive and control plans in landscape and architectural style, height, and color is needed to harmonize and protect the overall image of the site.

\section{Summary and Reflection}

The emergence of wearable devices makes it possible to record exact visually perceived images, providing new ideas, methods, and data for studies on visual image and relevant planning and design practice. With a higher demand on the refinement of urban governance, more attention should be paid to the protection, restoration, and construction of the vista view system in conservation of historical districts and places.

This study also sees inadequacies. First, the smallsize sampling in a narrow age range might lead to a poor representativeness; a larger-size and more diverse sampling is needed for further verification. Secondly, as the heavy data collection, identification, and analyses cost a huge manual work and time, computing technology and artificial intelligence assistance is expected in future studies. Thirdly, the appearance of plants in the video files changed during the five-month spanning study, which would somehow impact viewers' visual perception on the site and analyses of the vista view system. We hope this research and its findings can inspire similar research in the future. LAF

\section{PROJECT INFORMATION}

Location: Xicheng District, Beijing

Area (size): 800 meters in length

Project Leader: Liu Yifei

Project Team: Mou Tingting, Ha Rigui, Cheng Sifan, Zhang Yuqing, Ren Xiaohan, Liang Jingyi, Guo Chenxi, Chen Ruilin, Huang Ziwei, Nan Jingna, Xu Anyang, Liu Chang, Wu Jiaxin, Luo Yan, Li Yulin, Sun Pingtian, Ma Xinyu

Research Time: $2017 \sim 2018$

NOTE

Please be free to ask for the raw data via email.

REFERENCES

[1] Lynch, K. (1960). The Image of the City. Cambridge: MIT Press.

2] Lee, $Y$ \& Schmidt C. G. (1988). Evolution of Urban Spatial Cognition. Patterns of Change in Guangzhou, China. Environment and Planning A, 20(3), 339-351. doi:10.1068/a200339

[3] Michael, H. C., \& Stephen, J. P. (2002). The geography of tourism and recreation: Environment, place and space. New York: Routledge.

[4] Tang, Z. L. (1997). Descriptions and Explanations of Urban Spatial Structure: A Review of Research Development. Urban Planning Review, (6), 1-11, 63 .

[5] Gu, C. L., \& Song, G. C. (2001). The Study on the Urban Image and Its Application in the Urban Planning. City Planning Review, 25(3), 70-73, 77. doi:10.3321/j.issn:1002-1329.2001.03.019

[6] Herstein R. Jaffe, E \& Berger, R. (2014). Forever young: How can a branding destination strategy regenerate a city image? The case of Tel Aviv. Journal of Urban Regeneration and Renewal, 7(3), 211-223.

[7] Tapachai, N., \& Waryszak, R. (2000). An examination of the role of beneficial image in tourist destination selection. Journal of Travel Research, 39(8), 37-44.

[8] Shi, J. R., \& Duan, Y. Y. (2014). Research on the Circle Line Preference and Visitors' Image of the West Lake in Hangzhou. China Ancient City, (9), 37-42.

[9] Day, J., Skidmore, S., \& Koller, T. (2002). Image selection in destination positioning: A new approach. Journal of Vacation Marketing, 8(2), 177-186.

[10] Doersch, C., Singh, S., Gupta, A., Sivic, J., \& Efros, A. A. (2012). What Makes Paris Look like Paris? ACM Transactions on Graphics, 31(4), 1-9. doi:10.1145/2185520.2185597

[11] Liu, L. (2014). C-IMAGE: City cognitive mapping through geo-tagged photos (Master's thesis, Massachusetts Institute of Technology). Retrieved from http://hdl.handle.net/1721.1/90205

[12] Gao, J., \& Han, D. (2014). A Research on the Image of Historic Urban Blocks Based on Conten Analysis: A Case Study of Hengshan and Fuxing Roads in Shanghai. Tourism Science, 28(6), $1-12$

[13] Bartie, P., Mackaness, W. A., Petrenz, P., \& Dickinson, A. (2015). Identifying related landmark tags in urban scenes using spatial and semantic clustering. Computers, Environment and Urban Systems, (52), 48-57. doi:10.1016/j.compenvurbsys.2015.03.003

[14] Salesses, P., Schechtner, K., \& Hidalgo, C. A. (2013). The collaborative image of the city; Mapping the inequality of urban perception. Plos One, 8(7), e68400. doi:10.1371/journal. pone. 0068400

[15] Liu, Y. F., \& Li, X. (2017). Review of City Image Study Based on the Uprising Urban Landscape Iconology. Landscape Architecture, (12), 28-35.

[16] Long, Y., \& Zhou, Y. (2017). Pictorial Urbanism: A New Approach for Human Scale Urban Morphology Study. Planner, 33(2), 54-60.

[17] Liu, L. (2016). Research on City Image: From Big Data to Learning Era. Planning of 60 Years: Achievement and Challenges - Proceedings of Annual National Planning Conference 2016. Shenyang: Urban Planning Society of China.

[18] Li, Y., Zhao, M. X., Xu, Y., \& Chen, Y. L. (2017). Space Image of Multi-Scalar Urban Nightscape Represented by Photo Landscape on the Internet. Planner, 33(9), 105-112. doi:10.3969/ j.issn. 1006-0022.2017.09.017

[19] Tammet, T., Luberg, A., \& Jarv, P. (2013). Sightsmap: Crowd-Sourced Popularity of the World Places. In L. Cantoni \& Z. Xiang (Eds.), In Information and Communication Technologies in Tourism (pp. 314-325). Berlin and Heidelberg: Springer.

[20] Liu, L., Zhou, B. L., Zhao, J. H., \& Ryan, B. D. (2016). C-IMAGE: City cognitive mapping through geo-tagged photos. Geojournal, 81(6), 817-861.

[21] Cao, Y. H., Long, Y., \& Yang, P. F. (2017). City Image Study Based on Online Pictures: 24 Cities Case. Planners, 33(2), 61-67.

[22] Li, H. (2013). Spatial structure reorganization of historical towns based on city image - Taking Fubao Town as an example. Science and Technology Information, (9), 441.

[23] Zhou, Z. W., \& Sun, C. M. (2008). The Old City in Memory - Protection and Development of the Inner City Image. Anhui Architecture, (1), 15-17.

[24] Wang, F., Yan, L., Xiong, X. K., \& Wu, B. H. (2012). A Study on Tourist Cognition of Urban Memory in Historic Sites: A Case Study of Alley Nanluogu Historic Site in Beijing. Acta Geographica Sinica, 67(4), 545-556.

[25] Liu, Y. F., Fu, W. Wu, Y. Y., Xue, B. W. \& Wang, S. F. (2017). Web-Data Based Historic City Image Study: Taking the Old Town of Dingxing as an Example. Modern Urban Research, (8), 1-38. 